Portland State University

PDXScholar

1974

\title{
Oregon and the Blue Eagle: a Study of the Response of Oregonians to the National Recovery Administration
}

John Craig Bledsoe

Portland State University

Follow this and additional works at: https://pdxscholar.library.pdx.edu/open_access_etds

Part of the United States History Commons

Let us know how access to this document benefits you.

Recommended Citation

Bledsoe, John Craig, "Oregon and the Blue Eagle: a Study of the Response of Oregonians to the National Recovery Administration" (1974). Dissertations and Theses. Paper 2151.

https://doi.org/10.15760/etd.2149

This Thesis is brought to you for free and open access. It has been accepted for inclusion in Dissertations and Theses by an authorized administrator of PDXScholar. Please contact us if we can make this document more accessible: pdxscholar@pdx.edu. 
AN ABSTRACT OF THE THESIS OF John Craig Bledsoe for the Master of Arts in History presented May 15, 1974.

Title: Oregon and the Blue Eagle: A Study of tine Response of Oregonians to the National Recovery Administration.

APPROVED BY MEMBERS OF THE THESIS COMMTTTEE:

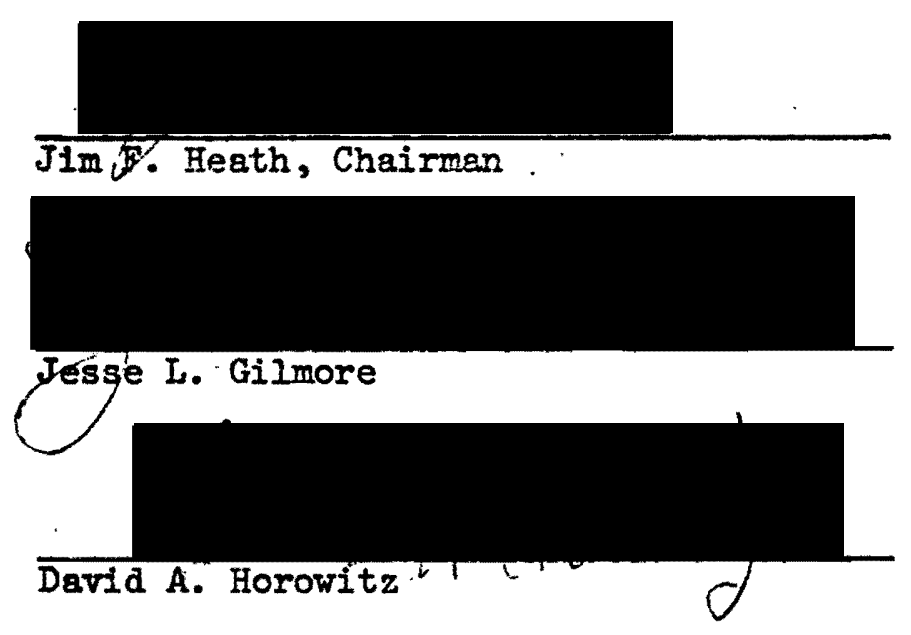

The original response of Americans to the National Recovery Administration (NRA) was almost unbounded enthusiasm in mid-1933. But the enthusiasm of the public, business and labor for the NRA noticeably declined by early 1934 and it continued to decline until the NRA was declared unconstitutional in May of 1935. The primary objective of this study is to determine whether the response of Oregon to the NRA followed that of the nation.

Focusing mainly upon the Portland metropolitan area, this study is based on information drawn from newspapers and other primary source materials available for the period during which the NRA was in existence. 
While this study does not purport to be a definitive analysis of the response of Oregon to the NRA, it does, hopefully, outline the general reaction of the state as a whole.

The response of Oregon to the NRA roughly parallels the nation's. The public, the business community, and the labor movement in Oregon responded to the $\mathrm{NRA}$ much in the same fashion as their counterparts nation-wide. 
OREGON AND THE BLUE EAGLE: A STUDY OF THE RESPONSE OF OREGONIANS TO THE NATIONAL RECOVERY ADMINISTRATION

\author{
by \\ JOHI CRAIG BLEDSOE
}

\begin{abstract}
A thesis submitted in partial fulfillment of the requirements for the degree of
\end{abstract}

\author{
MASTER OF ARTS \\ in \\ HISTORY
}

Portland State University

1974 
TO THE OFFICE OF GRADUATE STUDIES AND RESEARCE:

The nembers of the Cormittee approve the thesis of John Craig Bledsoe presented May 15, 1974.

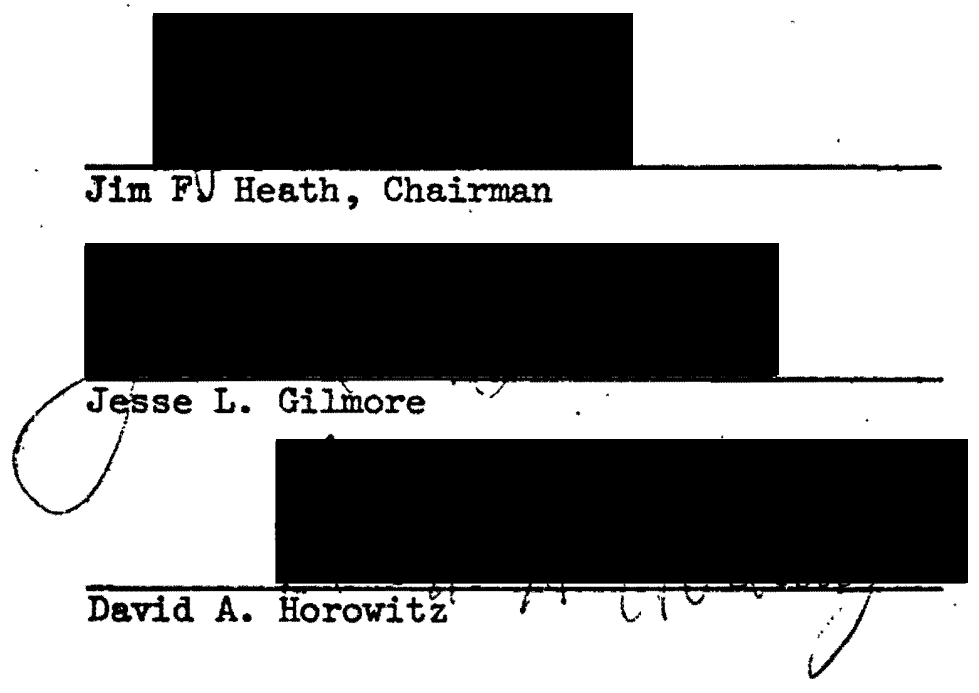

APPROVED :

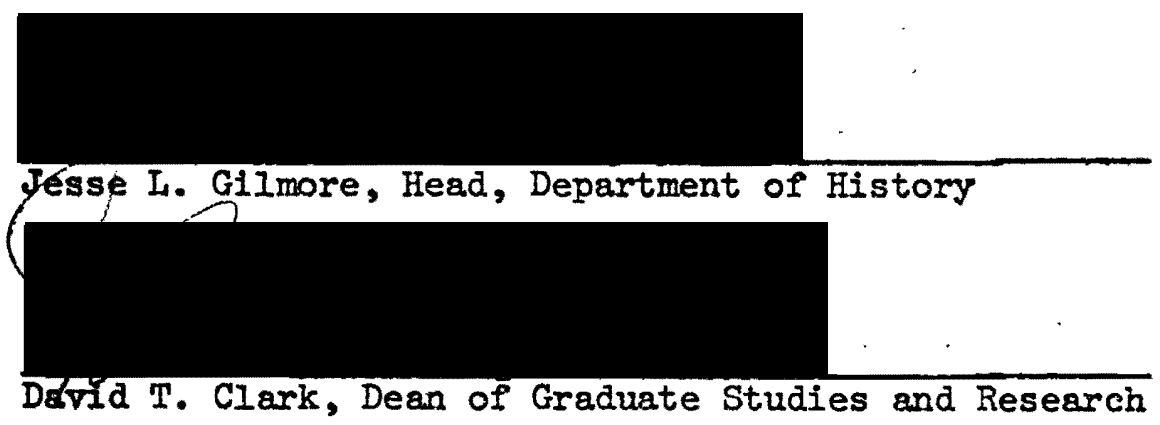

May 15, 1974 


\section{TABLE OF CONTENTS}

\section{PAGE}

CHAPTER

I THE NATIONAL RECOVERY ADMINISTRATION AT THE

NATIONAL LEVEL . . . . . . . . . . . . . . . 1

II OREGON AND THE NATIONAL RECOVERY ADMINISTRATION • • 20

III OREGON, THE KATION AND THE BLUE EAGLE:

COMPARISONS ARD CONIRASTS

41

BIBLIOGRAPHY

55 
CHAPTER I

THE NATIONAL RECOVERY ADMINISTRATION

AT THE NATIONAL LEVEL

An inescapable aspect of the first administration of Franklin Delano Roosevelt is the tremendous burst of activity that consumed Washington during the "Hundred Days" special Congressional session of March 9 through June 16, 1933. Roosevelt, in his inaugural address, had promised to America that he would pursue a program of action. And action there was, in abundance: fifteen major bills were passed by Congress in a little over three months. Working at a staccato pace, the 73rd Congress spewed forth a multitude of programs that attacked the Depression at nearly every level.

Unfortunately, much of what was approved by Congress in those hectic days which signaled the beginnings of the New Deal was hastily composed and very often ambiguous in its origins and character. The National Industrial Recovery Act serves as perhaps the best example of the confusion and ambiguity embodied within the early legislation of the New Deal. Further, the act provides an excellent example of the economic inconsistency of the experimental recovery programs of Roosevelt's administrations.

On June 16, exactly one hundred days after Congress had convened, the National Industrial Recovery Act (NIRA) was signed by Roosevelt. Considered to be the capstone to the flurry of legislation that had 
been passed before it, the NIRA was heralded by Roosevelt as what "History probably will record . . as the most important and farreaching legislation ever enacted by the American Congress. "I The act was divided into two main parts; the second of which dealt with public works and the taxes to finance them.

Title II of the NIRA, entitled "Public Works and Construction. Projects," created the Public Works Administration (PWA) and authorized it to spend up to a total of $\$ 3,300,000,000$ on a variety of profects ranging from construction of highways and low-cost housing to conservation of natural resources. Harold Ickes, Secretary of the Interior, was appointed head of the PWA, which was to be in effect for two years. ${ }^{2}$ But it was the first part of the NIRA, Title. I, which drew the most attention and publicity. 3

Title I, "Industrial Recovery," established the National, Recovery Administration (NRA) which was to oversee the guidelines set forth within its portion of the act. The objectives of the NRA were declared in rather vague and general terms in the first section of Title I: to provide for the general welfare, to remove obstructions to interstate and foreign commerce, to promote co-operative actions among trade groups,

ISamuel I. Rosenman, ed., The Public Papers and Addresses of Franklin D. Roosevelt, Vol. II: The Year of Crisis, 1933 (New York: Random House, 1938), p. 246.

2The Public Works Administration was eventually in existence for ten years, until June of 1943. In its lifetime, the PWA sponsored over 34,000 projects and spent about $\$ 6,000,000,000$.

3Ellis W. Hawley, The New Deal and the Problem of Monopoly: A Study in Economic Ambivalence (Princeton, New Jersey: Princeton University Press, 1966), p. 31 . 
to induce and maintain united action between labor and management under government supervision and sanctions, to eliminate unfair competition, to avoid undue restrictions on production, to increase consumption of products by increasing purchasing power, to reduce and relieve unemployment, and to improve standards of labor. The NRA, like the PWA, was to expire in two years.

Under the provisions of Title I, business groups and trade associations were permitted to formulate industry-wide "codes of fair competition," in order to limit production and raise prices through mutual agreement, without fear of anti-trust prosecution. In other words, industries were allowed to collude and cartelize, contrary to laws prohibiting such action like the Sherman and Clayton Acts, in hopes of preventing cut-throat competition and over-production. The government, through the NRA, reserved the power to accept or reject these codes of fair competition, to set up its own code when companies within an industry could not agree, and to enforce the codes. No industry proved too small for the NRA to tackle: codes eventually ranged from the Burlesque Theatrical and the Covered Button agreements to the Ice Cream Cone and the Pickle Packing ones.

In addition to the benefits business received in Title I, labor was given a position of legitimacy in the American economy through Section $7(a)$ of the NIRA. Described by William Green, President of the American Federation of Labor, as a "Magna Charta" for labor and compared with the Emancipation Proclamation by John L. Lewis, President of the United Mine Workers, Section $7(a)$ was indeed a giant step forward 
for the American worker. In Section $7(a)$, labor was guaranteed the right to collective bargaining--without managerial interference-freedom of cholce in organization, and maximum hours and minimum wages. 4

Title I of the NIRA was a product of three conflicting plans for economic recovery that were advocated by various individuals and groups throughout the 1930's. Each of these three plans approached the Depression from different directions.

In one corner were the neo-Brandeisians, inheritors of the New Freedom philosophy of Woodrow Wilson, who espoused a program of antitrust as being the solution to the Depression. In another corner were the successors of Theodore Roosevelt's New Nationalism, who felt that business self-government would take the country out of its economic quagmire. In the third corner stood those who fell roughly between the New Freedom and the New Nationalism; this group advocated a plan of government-business cooperation, or a "new competition," as the avenue toward recovery. Anti-trusters were on the political left. Those who wanted government-business cooperation were in the center. Spokesmen of business self-government stood on the political right. 5

${ }^{4}$ See Irving Bernstein, Turbulent Years: A History of the American Worker, 1933-1941 (Boston: Houghton Mifflin, 1969), particularly chaps. 1-7 for a general account of the effect of Section $7(a)$ upon labor in America.

Fone of these delineations are inflexible classifications. Hawley, New Deal and Monopoly, pp. 36-51, cites the following persons and groups as being advocates of the three conflicting plans for economic recovery during the formative and early stages of the NRA. (Shifts in attitude were, most certainly, possible. Also, plans espoused by particular individuals for economic recovery, in 1932 and 1933, were not necessarily Indicative of their social philosophies in toto.) Those on the political right who were advocates of business planning include: Henry I. Harriman, President of the American Chamber of Commerce; Gerard Swope, President of General Electric; Bernard M. Baruch; the American Bar Association; and 
The NIRA was Iittle more than enabling legislation that was the result of a compromise between the left, the right, and the center. It could have proceeded down any of those paths for recovery that were advocated by spokesmen for anti-trust, government-business cooperation, and business self-rule. However, it was the political center that spoke of government-business cooperation, as a solution to the Depression who won precedence over anti-trusting and business planning in the National Recovery Administration. But what eventually became of the concept of government-business cooperation embodied in the NRA was really closer to business planning or industrial self-rule with little or no control coming from Washington. This shift in the actual role of the NRA and 1ts relationship to the economy caused no small amount of dissension within the agency itself. 6

One of the more colorful aspects of the NRA was its flamboyant director, Hugh S. Johnson, and the campaign for public support he led. Appointed by Roosevelt as administrator of Title I on the same day the NIRA was signed by the President, the fifty-one year old Johnson was a

the National Association of Manufactures. Those in the center who spoke favorably of government-business cooperation (with business either as an equal or a junior partner) include: Rexford G. Tugwell; Alexander Sachs, a corporation economist; Charles A. Beard; Will Durant; George Soule; and John Dewey. On the left, anti-trusters and spokesmen for national economic planning include: Senators Hugo Black, William Borah, and Robert Wagner; Adolf Berle of Roosevelt's "Brain Trust"; Francls Perkins; and Felix Frankfurter.

6Hawley; New Deal and Monopoly, deals with the ambiguity and the conflicting goais of the NRA throughout Part I of his book; see especially chaps. 2,3 , and 5 . 
retired United States Army General who had been born and raised in the Cherokee Strip of Oklahoma. He had served as a lfaison between the Army and the War Industries Board during World War I and had been an offlcial of the Moline Plow Company and an associate of Bernard Baruch during the 1920's and the early thirties.

Johnson--an early "brain truster" for Roosevelt-was selected by the President as administrator of the NRA at the prompting of Raymond Moley; Roosevelt's Assistant Secretary of State and a key figure in the "Brain Trust." Johnson's familiarity with governmental organization and with big business were points in favor of his selection as NRA administrator.

Acting like a field marshall leading a civilian attack upon the Depression, Johnson drumed up popular support for the NRA with the Blue Eagle drive, begun in the mid-Summer of 1933. Johnson, when he realized that administrative machinery could not cope with the large number of code requests that flooded NRA offices after they opened, conceived of a "blanket code," known as the President's Reemployment Agreement (PRA).7

The PRA basically stated that small businesses, after they promised to conform to certain wage and hour restrictions, agreed not to raise prices, and said that they would not employ child labor, would be allowed to display an emblem--the Blue Eagle--which signaled their efforts toward recovery. It was expected that patriotic citizens would

$7_{\text {More than }} 200$ code requests were received by the NRA within the Iirst month after it opened its offices; 144 came in during the last hale of July, 546 in August. 
not patronize businesses which aid not display the Blue Eagie Insignia. The PRA was to be in effect for any given business until the entire industry of which that business was a part came under the authority of a regular NRA code. Otherwise, the length of time a business could operate under the PRA was indefinite.

To get as many businesses under the PRA as rapidly as possible, Johnson directed a patriotic campaign for popular support. Enlisting military jargon to give the BIue Eagle drive as much of a patriotic flavor as could be done, Johnson created a great deal of ballyhoo. and enthusiasm in the nation at large. The NRA became a mass movenert with an ". . army of a million and a half volunteer workers. . ." with field marshall General kugh S. Johnson giving his "shock troops" their marching orders. 8 Parades celebrated the NRA; speeches acclaimed it. Nearly 2,500,000 employers and 16,000,000 workers. signed the PRA within a few weeks; the Blue Eagle was to be found in countless store windows, on innumerable advertisements, and stamped upon a seemingly infinite number of products. Newly-born baby girls were named Nira. IRA ballads flooded the agency's desks. Beauty contests were held which picked as their winner Miss NRA. The wings of the Blue Eagle had indeed spread over America.

The administrative machinery of the NRA was, to say the least, a gargantuan and complex bureaucracy. To cope with the 557 basic codes

BNational Recovery Administration, Speakers' Division, Pointed Paragraphs for Speakers: The Blue Eagle Drive, in Voices of the American Past: Readings in American History, ed. by Morton Borden (Lexington, Massachusetts: D. C. Heath and Company, 1972), p. 299. 
and 208 supplementary codes it eventually formulated and approved, In addition to its adoption of numberless PRA's, the Washington staff alone of the NRA grew from around 400 in August 1933 to about 4,500 In early 1935. The network of administrative channels within the IRA Itself changed twice in organization during its two-year lifespan. Administrative development of the IRA consisted of three broad. phases: 1) the period of intense code-making, June 1933--March 1934; 2) the reorganization of the NRA for purposes of code administration and policy making, March 1934--September 1934; and 3) the general reorganization of the NRA and reorlentation of official policy, September 1934-May $1935 .^{9}$

Criticism of the NRA steadily mounted after the excitement of the Blue Eagle drive somewhat subsided. Therefore, on February 19, 1934, Roosevelt appointed the famous lawyer Clarence Darrow to head an Invest1gation and analysis of the NRA. Darrow was to report upon accusations that the NRA was hindering, rather than stimulating, recovery and that it was leaning too much in favor of big business. The National Recovery Review Board, led by Darrow, did a brief study and concluded that large corporations dominated the major NRA codes and that the small businessman, the worker, and the consumer were being squeezed out of any hope for recovery. The Darrow committee's preliminary report stated that there should be a return to free competition;

9Leverett S. Lyon, et al., The National Recovery Administration: An Analysis and Appraisal (Washington, D. C.: The Brookings Institution, 1935), pp. 47-82, discusses at length the phases of NRA administrative development. 
but its supplementary and final report urged adoption of socialized ownership, since free-market capitalism was just as nauseous to Darrow as the cartel-type organization fostered by the NRA. 10

Hugh Johnson's tenure as director of the NRA ended when he resigned in spetember 1934. His experience in the NRA constituted both a rewarding and a frustrating period in his life. He was tremendously proud of what the NRA had done, particularly for labor: "It abolished child labor. It ran out the sweatshops. It established the principle of regulated hours, wages, and working conditions. It went far toward removing wages from the area of predatory competition. It added to the rights and the freedom of human labor." 11 However, Johnson's verbosity and his uncompromising character earned him and the NRA no mean number of critics. Furthermore, criticism toward the NRA in general frequently tended to be directed at Johnson himself. To be sure, the NRA did make some great strides for the American worker. But it also acquired the title of the "National Run Around" from many labor spokesmen because Johnson unwelcomely intervened in so many labor disputes and strikes. It was called the "National Retrogressive Act" by those on the far left. The NRA also stopped the deflationary spiral of 1933. But it did not stimulate recovery; it

10William E. Leuchtenburg, Franklin D. Roosevelt and the New Deal, 1932-1940 (New York: Harper \& Row, 1963), pp. 67-68.

II Hugh S. Johnson, The BIue Eagle Prom Egg to Earth (Garden City, New York: Doubleday, Doran \& Company, 1935), p. x. 
merely kept things from getting worse. In fact, the NRA probably hindered recovery through its support of restrictionism and price raising. 12

The accusations of small businessmen and anti-trusters that the NRA furthered, rather than prevented, the formation of monopolies cannot be substantiated to any great degree. Small businessmen were actually more disgruntled by the fact that Section $7(a)$ prevented them from $a$ continuing policy of labor exploitation. Anti-trusters had been against the NRA ever since they realized it would not adopt a stringent policy of "trust busting." 13

Johnson's successor as the NRA's closest contact to the President was Donald R. Richberg, a man who had just as volatile a personality as Johnson. But Richberg was capable of masking his feelings behind a bland exterior. Richberg had been Johnson's general counsel and had also been at almost constant loggerheads with the General. Richberg did not become National Recovery Administrator; Roosevelt abolished the office and replaced it with the newly-created National Recovery Board. 14

12 Hawley, New Deal and Monopoly, p. 104; Leuchtenburg, FDR and the New Deal, p. 69.

13Leuchtenburg, FDR and the New Deal, p. 69.

14 Regarding Richberg's work in the NRA see his The Rainbow (Garden City, New York: Doubleday, -Doran \& Company, 1936) and Hy Hero: The Indiscreet Memoirs of an Eventful but Unheroic Life (New York: G. P. Putnam's Bons, 1954), chaps. XIII-XVII. Helpful, but not overly insightful, on Richberg and the NRA is Thomas E. Vadney, The Wayward Liberal: A Political Biography of Donald Richberg (Lexington, Kentucky: The University of Kentucky, 1970), chaps. VI-VIII. 
The National Recovery Board was composed of representatives of management, labor, and the public. The Board was incapable of any real reorientation of NRA policy because overhauling of codes required Congressional approval. And Congress itself was not the strongest supporter of the NRA in late 1934 and 1935. Congressmen's constituencies were their political futures; public opinion, which was little more than halthearted for the NRA, forbid much Congressional support for 1t. 15

The constitutionality of the NRA was tested in the Supreme Court case of Schechter Poultry Corporation $v$. the United States, popularly known as the "Sick Chicken" case. Richberg had attempted to relax some of the codes and to abandion some of the price-fixing rules of the NRA in hopes of steming criticism. But steming criticism became a moot point when the Supreme Court declared the NRA unconstitutional on May 27,1935 . In a unanimous decision, the Court stated the unconstitutionality of the NRA on two grounds. First, it contradicted the constitutional principles of separation of power by its delegation of power by Congress to the, executive. Second, it included a lederal regulation of intrastate commerce as well as interstate commerce. The demise of the NRA in the "Sick Chicken" decision did not cause much sadness on the national level. Large segments of the three groups the New Deal attempted to push toward recovery--consumers,

15 Hawley, New Deal and Monopoly, pp. 137-36; Arthur M. Schlesinger, Jr., The Age of Roosevelt: The Coming of the New Deal, 1933-1935. (Boston: Houghton Mifflin, 1958), p. 166. 
workers, and businessmen--had become critics of the NRA as early as the beginning of 1934. Consumers complained of high prices. Labor contended that the IRA favored management more than the worker. Small businessmen believed that the NRA was shoving them out of the marketplace in favor of big business and that it was fostering monopolies. Big business felt that the government was exercising too much control. over Its economic affairs and labor policies. 16 Roosevelt had asked Congress for a two-year renewal of the NRA in February 1935; but even he confessed privately to Frances Perkins, his Secretary of Labor, that ". . the whole thing is a mess. It has been an awful headache. Some of the things they have done in the NRA are pretty wrong. . . " 17 Historical precedent for the NRA rested squarely upon the example of the War Industries Board (WIB) of World War I. The WIB, under the leadership of Bernard Baruch, had effectively coordinated purchasing, allocated raw materials, controlled production, and supervised labor relations for the domestic war-time mobilization of the American economy. Further, anti-trust action was suspended for all practical purposes while the WIB directed the economy. The WIB had proved to be a coordinating agency that. was a mutually advantageous experience for labor, industry, and government during the First World War. Therefore, many people who had had experience in, or contact with, 16 Hawley, New Deal and Monopoly, p. 104; Leuchtenburg, FDR and the New Deal, p. 67 .

17 Frances Perkins, The Roosevelt I Knew (New York: Harper \& Row, 1946), p. 252 . 
the WIB looked back upon it with a particular fondness during the early thirties. ${ }^{18}$

Woodrow Wilson's Secretary of Commerce, William McAdoo, proposed a "Peace Industries Board" in mid-1931. Bernard Baruch, the former chairman of the WIB and a mutual friend and business associate of Hugh Johnson, publically advocated economic planning, for the economically depressed nation, along the lines of the WIB in 1930 and again in early 1933. Gerard Swope, President of General Electric and the person who had succeeded Johnson on the WIB, and who was also an early spokesman for government suspension of anti-trust laws, sat on the Industry Advisory Board of the NRA. Roosevelt himself, as Assistant Secretary of the Navy, had had contact with the WIB. He offered this defense of the NRA:

18 Hawley, New Deal and Monopoly, pp. 23, 135; Leuchtenburg, FDR and the New Deal, pp. 57-58; Schlesinger, Coming of the New Deal, p. 176; Charles Frederick Roos, NRA Economic Planning (New York: Da Capo Press, 1971), pp. 4, 35; Barton J. Bernstein, "The Conservative Achlevements of Liberal Reform," in The New Deal: The Critical Issues, ed. by Otis L. Graham, Jr. (Boston: Little, Brown, 1971), p. I5I. Johnson, The Blue Eagle, makes continual reference'to the experience he received in his relations with the WIB as having direct bearing upon the NRA; see particularly pp. 101, 114-15. Two especially provocative and usefur articles which deal with the aspects of direct continuity between the WIB and the NRA are written by William F. Leuchtenburg, "The New Deal and the Analogue of War," in Change and Continuity in Twentieth-Century America, ed. by John Braeman, Robert H. Bermer, and Everett Walters, Harper Colophon Books (New York: Harper \& Row, 1966), pp. 117-23, 133; and Gerald D. Nash, "Experiments in Industrial Mobilizations: WIB and NRA," Mid-America, XIV (July, 1963), 157-74. 
I had a part in the great cooperation of 1917 and 1918 and it is my falth that we can count on our industry once more to join in our general purpose to lift this new threat and to do it without taking any advantage of the public trust which has this day been reposed without stint in the good faith and high purpose of American business. 19

The nation had been able to cope with a federally-directed industrial mobilization during World War I. The WIB experience thus served as a model for a government-business partnership fifteen years later, when the nation was again confronted with a crisis situation.

That many government officials and administrators of the NRA recelved experience in the WIB does not necessarily cast any positive or negative qualities upon the NRA. However, the fact that the NRA was modeled so closely upon the WIB does indicate the inherent weaknesses of the NRA.

Most obviously, the NRA was actually an unimaginative thrust by the government into the concept of close cooperation with business for the regulation, and hopefully stimulation, of the economy. As Gerald D. Nash says, "Establishment of the NRA . . was not conceived as a novel and untried experiment in industrial self-rule, but as a resusitation of a tried and proven remedy, developed only after much experimentation, the old War Industries. Board." 20 Both Nash and William E. Leuchtenburg point out that domestic America during World War I was an unsatisfactory model for economic mobilization during the

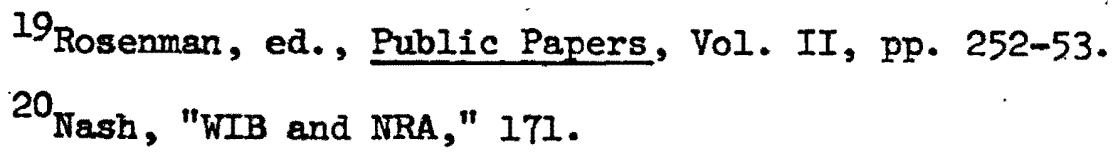


Depression because problems Roosevelt faced in 1933 were far and away different than those that Wilson faced in 1917-1919. 21

College survey texts take two approaches in their coverage of the NRA. While some texts generally offer a swift overview of the NRA with little or no historical interpretation of it, others tend to neatly tuck the NRA into their discussion of the Hundred Days and give an interpretation of it within the larger conceptual framework of the New Deal and its significance in history. 22

Historians loosely falling under the category of the "New Left" philosophy differ, in their interpretation of the New Deal, from those coming under the classification of the "Liberal-Democratic" school of thought. While the Left says that the New Deal was a conservative movement, Iiberal-Democratics contend that it constitutes at least a halfway--if not an entirely--revolutionary epoch in American history.

${ }^{21}$ Indeed, Leuchtenburg, "New Deal and Analogue," pp. 142-43, cogently argues that the entire New Deal rested upon the analogy of World War I. He contends that the very need for and usage of the war experience as an example for action reveals both a weak tradition of reform and a reluctance of the American people to recognize and accept the growth and the power of the federal government.

22 This is based upon a random sampling of texts. Those which fall into the first category include: John M. Blum, et al. , The National Experience: A History of the United States (3rd ed.; New York: Harcourt Brace Jovanovich, 1973), pp. 633-34, 640; Richard N. Current, T. Harry Williams, and Frank Freidel, American History: A Survey (3rd ed.: New York: Alfred A. Knopf, 1971), pp. 643-644; Carl N. Degler, et al., The Democratic Experience: A Short American History, Vol. II (3rd ed.: Glenview, Illinois: Scott, Foresman and Company, 1973), pp. 211-12, 215; Forrest McDonald, Leslie E. Decker, and Thomas P. Govan, The Last Best Hope: A History of the United States, Part 3 (Reading Massachusetts : Addison-Wesley Publishing Company, 1972), pp. 836, 844; and Samuel Eliot Morison, Henry Steele Commager, and William E. Leuchtenburg, The Growth of the American Republic, Vol. II (6th ed.; New York: Oxford Untversity Press, 1969), pp. 494-97. Texts which come under the second 
Arguments between historicel camps regarding the NRA roughly follow the same lines of interpretation of the New Deal.

Historians are in general agreement that the NRA was basically a failure for the economy as a whole. They are also in agreement that the NRA tried to do too much at once in order to be a really effective stimulus toward recovery. They argue that NRA policy came to be dominated by big business, while the worker, the small businessman, and the consumer were left out in the cold. Disagreements arise over whether the NRA was conservative or revolutionary in nature, or whether it was both. Perhaps the most proper interpretation--if indeed an interpretation may ever be "proper"--of the NRA should be that it was both conservative and revolutionary at the same time. The NRA's conservatism lay in its stated goal: to bring about recovery to what had been in existence before 1929. Its main attribute of radicalism was its foray into the world of private enterprise during peacetime.

category include: Peter N. Carroll and David W. Noble, The Restless Centuries: A History of the American People (Minneapolis: Burgess Publishing Company, 1973), pp. 430-431; John A. Garraty, A Short History of the American Nation (New York: Harper \& Row, 1974), pp. 420, 242, 429; Richard Hofstadter, William Miller, and Daniel Aaron, The United States: The History of a Republic (2nd ed.; Englewood Cliffs, New Jersey: Prentice-Hall, 1967), pp. 717-19, 725-26, 728-29; and Edwin C. Rozwenc, The Making of American Society: An Institutional and Intellectual History of the United States, Vol. II (Boston: Allyn and Bacon, 1973), pp. 350-53, 361-62, 366, 369, 373. 
Taken as a whole, there is a relatively abundant amount of published historical writing available which discusses the NRA. However, much of it has very specific limitations.

Most of the material which has been written on the NRA must be gleened from monographs which discuss, among other things, the economic aspects of the Roosevelt era, or labor in the 1930's, or Roosevelt himself, or the New Deal in general. The number of scholarly articles which discuss the NRA within the broad conceptual framework of the New Deal are in an almost infinite supply. However, articles published within the last fifteen years which deal specifically with the NRA, or some aspect of it, are not plentiful. The bulk of published material dealing with the NRA consists of articles appearing in both "popular" and scholerly periodicals, book-length surveys, and government-sponsored analyses-all of which were written during the short lifespan of the NRA or not long afterward. As the economic historian Broadus Mitchell commented in 1947: "The National Industrial Recovery Act and the National Recovery Administration left a large literature of description, praise, and dispraise." 23 And most of this literature borders upon the fine line between classification as either primary or secondary source material. 24

23 Broadus Mitchell, Depression Decade: From New Era Through New Deal, 1929-1941 (New York: Harper \& Row, 1947), p. 424.

${ }^{24}$ In relatively recent articles and monographs which discuss the NRA, authors rely heavily upon the Congressional Record and various Congressional committee reports: the Darrow report; Johnson, The Blue Eagle; Lyon, et al., The National Recovery Administration; and Roos, NRA Economic Planning, is the most frequently cited source; however, besides being published in 1937, it also has fairly skimpy documentation. 
The complete records of the NRA are contained in the National Archives (Record Group 9); in microfilm form the records take up 186 rolls which are cataloged by industry. Thus, it is almost, if not entirely, impossible to examine the full records of the NRA.

As a result of the sheer size of the official NRA records, historians have to pick and choose what they research while also having to determine how deeply they are willing and able to delve into the history of the NRA. Therefore, the reader is presented with either very broad overviews of the NRA or with very narrow and specific views of 1t. To this writer's knowledge, no published state studies of the NRA exist. The NRA in itself is dealt with little in conjunction to the New Deal in the states. One unpublished work, a Reed College Senior Thesis which was written in 1934, touches upon the NRA in Oregon with emphasis upon the lumber industry, the primary industry of the state. 25

The present study will attempt to plow some fertile soil in state studies of the New Deal by examining the NRA in Oregon. James $T$. Patterson comments that there is a ". . great amount of work which may profitably be begun in the field of state history... "In the history of the New Deal. 26 It is hoped that this thesis will offer a contribution to the history of Oregon and the NRA.

25Francis Clare Vause, "The Administration of the National Industrial Recovery Act with Particular Reference to the Lumber Industry" (unpublished Senior thesis, Reed College, June 1934).

26James R. Patterson, The New Deal and the States: Federalism in Transition (Princeton, New Jersey: Princeton University Press, 1969), p. 218. 
Oregon during the I930's may not be termed either a typical or an atypical state in comparison to the other forty-seven states; obviously, every state possesses unique characteristics. But an examInation of the NRA on the state level, using Oregon as a test case, should prove useful as more of a grassroots view of the NRA than the broad national or the very specific approaches which are currently given it by historians.

Historians are in accord as to how the NRA operated on the national level and how the American people reacted to it. The general objective of this paper is to answer the question: Does Oregon's response to. the NRA follow the response of the nation? 


\section{CHAPTER II}

OREGON AND THE NATIONAL RECOVERY ADMINISTRATION

\section{"Let's Make the Blue Eagle Scream!"}

Hugh Johnson, during a meeting in mid-July of 1933, was in a quandary over how to arouse national support for the NRA. World War I, he sald, had been less real for most Americans than the Depression. He declared that "'Almost every individual has either suffered terribly, or knows of friends and relatives who have; so there is waiting here to be appealed to what I regard as the most fertile psychology that you could imagine. . . I think this has anything that happened during the War backed off the board." I Not long after this meeting, the President's Reemployment Agreement was initiated by Johnson.

Before the PRA in the late summer of 1933, the reality of the NRA in Oregon was practically nonexistent for business, for labor, and especially for the public. Business knew that it would be governed in its practices by the government, but very few NRA codes had been written before the PRA became effective that had any impact upon Oregon's business community. A similar uncertainty existed for labor. For the Oregon public the NRA was a mysterious federal agency which promised to speed recovery from the Depression.

${ }^{1}$ Special Industrial Recovery Board, Proceedings, July 18, 19, 1933; quoted in Schlesinger, Coming of the New Deal, p. 113. 
Oregonians vaguely grasped the NRA as an essential part of Roosevelt's New Deal, but had little idea of how it would actually Influence their everyday lives. Although the NRA, like the New Deal in general, interested almost everyone, it is questionable whether very many people really understood just exactly how the NRA was to be their economic salvation. The NRA, like most newly-created governmental bureaucracies-particularly before the rise of mass media--was understood little by grassroots America. Even today it is dubious whether federal bureaucracies are understood by many people. With the beginning of the PRA and the Blue Eagle drive, the NRA became a reality for Oregonians.

Edgar Freed, a Portland attorney, was appointed General in charge of the metropolitan area Blue Eagle drive. Freed later became the State Director of the NRA and eventually State Director of the National Emergency Council (NEC). A Phi Beta Kappa from Harvard Law School who had served as an officer in the Army during World War I, Freed had a number of "officers" with military titles working under him in an effort to coordinate the Blue Eagle campaign. He made the. PRA and the NRA directIy analogous to war when he said that:

This is a. war. It will be conducted with the same organization used in war. Every resident of Portland, either directly or indirectly, will be affected by the mobilization of these soldiers. 2

$$
\text { 20regonian, Aug. 4, 1933, p. } 1 .
$$


Freed's "soldiers" came in every shape and form; they were troops which brought Portland to a temper which bordered upon mass hysteria.

The first troops of the Blue Eagle drive to assemble were Portland's businessmen when, on July 27 , over $4,000^{3}$ Portland employers Jammed the public auditorium and pledged themselves to sign and uphold the PRA. While Boy Scouts circulated preliminary PRA sheets for signatures, businessmen Iistened to Governor Julius I. Meier, Amedee M. Smith, the Portland Chamber of Commerce's president, and Walter W. R. May, the Chamber's manager, speak of the high purpose of the NRA and of the buisinessmen's patriotism. With a great deal of commotion and. boosterism, those present approved of appointing a vigilante committee of one hundred to check on "slackers" and spoke confidently of prosperity being at their doorstep. The meeting kicked off the Blue Eagle drive in Portland. It now became impossible for anyone to ignore the Blue Eagle, for the symbol appeared everywhere one went and upon almost everything one saw.

Newspapers carried scores of advertisements using the Blue Eagle and the slogan, "We Do Our Part." The ads coupled the hope of prosperity to be achieved through the Blue Eagle with the bargains to be found in the stores which were advertising. A prime example of this sort of advertisement was placed by the Portland retailers 0lds, Wortman \& King In the Oregon Labor Press in early September:

3 Statistics cited in this chapter which are drawn from newspaper accounts are probably inflated. These figures were, nevertheless, what the reading public was presented with at the time. 
Good Times ARE Coming Back

The National Recovery Administration is in full swing and

everywhere is evidenced the effects of the Blue Eagle.

Olds, Wortman \& King is happy to have a part in this forward

march to real prosperity--bringing you greater and greater

values for your money.

Onward America! Onward Oregon! Let's Go! 4

However, not every advertisement incorporated the Blue Eagle with an effort to sell something, as evidenced by the following ad by the

Oregonian which uses boosterism--and the analogy to war:

Let's follow the Blue Eagle! Just as Liberty Bonds won the war in '18, so the Blue Eagle. can lead us to victory over depression today...

Let's make the Blue Eagle scream!

But not only did newspapers contain scores upon scores of advertisements which used the Blue Eagle, they also carried lists of employers who signed the PRA--lists which typically occupied over three full columns of newsprint. 6

PRA applications from Oregon and Idaho--Idaho comprised a NRA district with Oregon in 1933--flooded into the Portland headquarters of the Blue Eagle drive at the rate of two to three hundred a day. By late August, 24,869 employers and 95,478 workers from Oregon and Idaho had signed the PRA. By late September, 31,151 employer applications

${ }^{4}$ Oregon Labor Press, Sept. 1, 1933, p. 7.

5Oregonian, Sept. 18, 1933, p. 3.

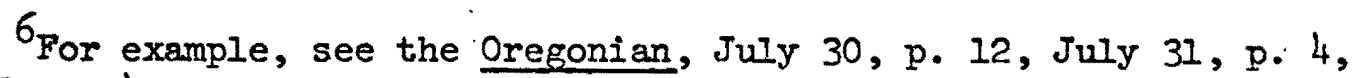
Aug. 2, p. 4, 1933. 
for the PRA, of which approximately two-thirds were from Oregon, had come to Blue Eagle drive offices. $T$. In Portland, less than one percent of around 12,000 metropolitan area employers were without a Blue Eagle in early September. 8

The Portland-area consumer was also a part of the Blue Eagle troops. Five hundred distribution points--booths in banks, large retail stores, and all of Portland's three hundred gas stations--were set up to encourage Portlanders to sign PRA consumer pledge cards and to give away Blue Eagle window and windshield stickers. By late September, over ninety-five percent of the city's homes had signed the consumers' pledge. Approximately 298,400 Portlanders had signed the pledge. 9

The enthusiastic boosterism and hoopla of the late stumer and early fall climaxed on October 5, when Portland held a Northwest mayors' conference in the afternoon and hosted a Blue Eagle parade in the evening. Civic activities began at two in the afternoon and ended some nine hours later. 10

Portland Mayor Joseph K. Carson met with eighteen Northwest mayors from cities as far away as Seattle, Tacoma, Medford, and Seaside as p. 7 .

TOregonian, Aug. 20, p. 12, Aug. 27, p. 6, Sept. 22, 1933,

$$
\begin{aligned}
& \text { 8oregon Journal, Sept. 6, 1933, p. I. } \\
& \text { 9. Oregon Journal, Sept. 6, 1933, p. 1; Oregonian, Sept. 24, } 1933 \text {, }
\end{aligned}
$$

10The following section on the Portland NRA celebration is taken from the Oregonian, Oct. 6, 1933, pp. $1,4,6$. 
well as those from nearby Vancouver, Camas, Troutdale and Oregon City at the Portland Chamber of Commerce in the early afternoon. Every mayor present considered the NRA as basically a success and encouraged cooperation by the nation's leaders so that the rest of the New Deal's program might proceed rapidiy.

Later the dignitaries and between 125,000 and 150,000 spectators who crowded the streets cheered as paraders, variously estimated at from 42,000 to 75,000 in number, marched to the tune of "Happy Days Are Here Again" for over three and a half hours in balmy Indian Summer weather. School children-who numbered somewhere between 8,000 and 12,000 and who comprised the largest single group in Portland's NRA parade--carried a sign which read "America Must Have Educated Citizens for the NRA." "Old Man Depression" met his doom under a chugging steamroller. Civilian Conservation Corps troops marched with axes, shovels, and picks swung over their bare shoulders. The Oregonian approvingly commented that "Enthusiasm ran high and free . . . Everyone felt that it was a march to prosperity. ..."Il Walter W. R. May, manager of the Portland Chamber of Commerce, boasted that "This parade is the largest NRA march held in the United States, with the exception of that in New York city[sic]. . " I2 In sheer numbers, the parade was the largest in Portland's history, with more people turning out to cheer the Blue Eagle than had previously cheered Charles Ifndberg, or Theodore Roosevelt, or Woodrow Wilson.

$11_{\text {Oregonian, }}$ Oct. y, 1933, p. 1.
12 Oregonian, Oct. 6,1933, p. 4. 
Oregonians had made the Blue Eagle scream, and the NRA had become a reality; prosperity, however, had not returned. The Blue Eagle drive helped to convince Oregonians that they could march straight out of the Depression. But, unfortunately, the Depression did not end for Oregon on October 5.

After the excitement of Portland's NRA parade, public interest in the NRA--at least as measured by patriotic appeals for support of 1t--declined noticeably. Retail businesses still displayed the Blue Eagle in their advertising, but nothing appeared in newspapers which came close to pre-parade advertisements. The Blue Eagle symbol became a proforma of display for businesses; effusive rhetoric in support of the IRA disappeared from virtually all advertisements.

The NRA had slipped to a position of being a half-reality for the Oregon public by late 1933. Almost like that ever-elusive prosperity that had been lost in the early thirties, so too the emotionalism, positivism, and boosterism of Oregonians for the NRA dwindled.

The Business Community and the NRA

Oregon's business community cannot be treated as a single unit when dealing with its response to the NRA. Both the size and the location of a business were determining factors in the state's business sector and its response to the $\mathrm{NRA}$.

Small service establishments-businesses employing five or less persons--located in towns of less than 2,500 population and not in a metropolitan area were exempt from obligations under the PRA; this exemption was continued with regard to NRA code provisions. A large 
portion of Oregon's business community can be excluded from the discussion, since--like most Western states--the buik of the population Iived in towns of Iess than 2,500 not in a metropolitan area. ${ }^{13}$ Most businesses in small communities were probably service establishments that were family operated and that employed less than five people--gas stations, dry goods stores, and grocery stores are perhaps the best examples.

The location of a business establishment in Oregon limited the business community's response to the NRA. The organization of the state offices of the NRA prohibited much contact with towns and cities not wlthin the Portland metropolitan area. A field adjustor was appointed in March of 1934, but most of his time was spent in the Portland office. And Edgar Freed made no effort to organize local adjustment agencies. The majority of complaints to come into the state office came from the Portland area, probably because of the lack of facilities for dealing with complaints elsewhere in the state. 14

Once it is taken into consideration that both size and location of businesses determine, to a large degree, a discussion of the business sector's response to the NRA, it is a logical conclusion to deal almost exclusively with the Portland area business community. ${ }^{15}$ Consequently,

13 In 1930, twenty-two communities in Oregon had a population of 2,500-10,000; six cities had populations of over 10,000. U. S., Department of Commerce, Bureau of the Census, Fifteenth Census of the United States, 1930: Population, III, 629, 630 .

${ }^{14}$ Vause, "Administration of the NIRA," p. 67.

15While there were twenty-seven tows or cities, besides Portland, which had populations of over 2,500 in 1930 , the majority of them were not within easy driving distance- -50 miles--of Portland. 
the following discussion will focus mainly upon the state's largest city.

After the excitement of the Blue Eagle campaign died down, the business community of Portland continued to display its Blue Eagle placards and to incorporate the Blue Eagle "We Do Our Part" emblem and slogan in its advertising. But gone forever was the boosterism of the late summer and early fall of 1933. Although business did not ignore the NRA, it is questionable whether business really supported it. It is doubtfuI whether any business during the thirties was willing to support a program which forced it to limit production, raise prices, pay its employees a minimum wage, and not work its employees over a maximum number of hours. That the NRA was federal law and not a voluntary program points to what must have been either an unwillingness on the part of a greater portion of American business to accept the NRA or a dubious attitude on the part of government that business would respond unfavorably to the NRA. More than anything else, businesses' use of the Blue Eagle in advertising can probably be counted toward good public relations.

Whether the Blue Eagle was actually effective as a public relations device depended upon the area in which a business was located and the type of clientele to which it catered. The Cresent Laundry, which was located in a predominantly working-class and lower-class district of East Portland, suffered no loss in business after its Blue Eagle was removed for violation of Section $7(a)$ and price cutting. 16 But 16 LIP, March 9, 1934, p. 1. 
other businesses in more well-to-do areas of Portland which lost their Blue Eagles either went out of business or struggled to stay in business because of adyerse public sentiment. 17 Meier \& Frank, a prominent downtown Portland retail store, was the most vigorous user of the Blue Eagle as an advertising aid. It even had a "Blue Eagle Day Sales" promotion in November of 1934 during which it gave away NRA consumer pledge window stickers and used advertisements like the following:

Much stress is properly laid on the importance of the 'consumers co-operation' in the NRA program, and Meier \& Frank, through its Blue Eagle Sale, rewards the consumer for this co-operation in a most practical way . . . good money saved on good goods ... wanted things, needed things, things for person, for home, for gifts. 18 .

To a large degree, it depended upon where a business was situated and to whom it catered as to what would happen to its patronage if it lost its Blue Eagle.

One particular incident in Portland merits notice when discussIng the NRA and business. The owner of a business voluntarily surrendered his Blue Eagle in December of 1933 because of what he publically termed the "outrageous" prices that he had to charge his customers according to code provisions. I. I. Starr, proprietor. of the Portland Cleaning Works, insisted that he was paying his fortythree employees over the wage scale set by the NRA while also staying

17 Vause, "Administration of the NIRA," pp. 22-23; Oregonian, March 15, 1934, p. 1; OLP, ApriI 6, p. I, Sept. 28, 1934, p. I. ${ }^{18}$ Oregonian, Nov. 18,1934, p. 13. 
under maximum hour guidelines. He stated that he would not "gouge the public" by charging the Portland code prices which were formulated and accepted by twenty-four out of a total of 300 Portland cleaners. Starr-who said that other owners were also dissatisfied with the code-maintained that he was in sympathy with the NRA; but he felt that if he charged the code price for his services, he would be forced to lay off half his workers because the public would not patronize his establishment at such high prices. 19 But Starr's public statements do not tell of the entire story behind his giving up of the Blue Eagle. Starr's relationship with Edgar Freed was not the best. Starr privately commented that "If he [Freed] had treated me respectably and in the proper light, it would have been entirely different." Denouncing Freed in no uncertain terms for his offensive attitude and general incompetence, Starr stated that "Mr. [Frank] Messenger [Executive Assistant of the Oregon NRA] is a gentleman . . I do not doubt that if $\mathrm{Mr}$. Messenger had been in charge of the office this thing could have been cleared up."20 Starr was obviously. biased, since he did forfeit his Blue Eagle, but even while statements like his might be discounted, they certainly cannot be ignored. Starr was alone, perhaps, in his

19 Oregonian, Dec. 19,1933 , p. 7. It is interesting to note that the publicity of Starr's action attracted rather than repelled, customers; Vause, "Administration of the NIRA," p. 133.

${ }^{20}$ Quoted in Vause, "Administration of the NIRA," p. 60. Frank Messenger had been district compliance director for Oregon and Idaho before the NRA Compliance Division was reorganized along state lines in early 1934. 
recorded verbal abuse of Freed; however, he was not alone in the Oregon business community in being dissatisfied with NRA codes.

Iumber industry officials basically supported the NRA in their public statements. Colonel William B. Greely, who was Chief Forester of the United States before becoming Secretary-Manager of the West Coast Lumbermen's Association, commented at a meeting held in Portland of the Northern Pacific Section of the Society of American Foresters that: "The national lumber code is functioning satisfactorily. . . . Two results already are outstanding. These are production control and establishment of cost production prices." 21 . But the general sentiment of Oregon's lumber industry towards MRA codes was one of discontent. 22

Lumber mill operators as a group were not pleased with the NRA lumber codes under which they operated, especially regarding prices. A general belief in the lumber industry was that minimum retail prices under the lumber code were too high for the market. Lumbermen believed that retail code prices for their products were in fact so high that new butlding was prohibited. Ben H. Hazen, President of the Oregon Savings and Loan League, shared this belief. Most certainly, code prices were too high for the lumber industry of the Northwest to compete in the

\section{IOregonian, March 15, 1934, p. 6.}

22 The following section on the response of Oregon's lumber industry to the NRA is derived for the most part from Vause, "Administration of the NIRA," chap. 4, "The NRA in the Lumber Industry." Only direct quotations will be cited. Vause relied heavily upon personal interviews with and private letters from lumber industry personnel in the compilation of this particular chapter of his thesis. Inquiries were sent to small, medium and large lumber mill operators; however, only one of the replies from large operators discussed the questions which were put to them by Vause.' 
world market. The Northwest was exporting three times as much Iumber as British Columbia in the $1920^{\prime}$ 's, but by the early thirties it was exporting one third as much as British Columbia.

Small back-woods operators--who were typically a very independent group and who were accustomed to a "hip pocket" form of bookkeeping-simply did not understand what the NRA was or how it was to help them. One back-woods operator wrote that:

The code authority seems to me to be verry [sic] strict and they pester me with a lot of literature that $I$ don't understand and they don't answer the questions $I$ ask them when $I$ write to them. Really I don't think the small mills are getting a fair deal. 23

To many small operators, the NRA appeared to be nothing more than a federal bureaucracy which was incomprehensible both in its means and ends. As one operator said,"... theres [sic] entirely to [sic] much code literature to try to read it ail. . . " 124

Many lumber mills used price "chiseling" as an alternative to losing business because of the prices they were supposed to charge their customers. Operating in a fashion reminiscent of the bootleggers of the 1920's, lumber mills lowered their lumber a grade or two and sold it for the code price of lesser quality lumber or sold their product on account at the code price and accept a percentage of that billing as full payment. One Iumberman remarked that "Ninety percent of the industry lay [sic] awake nights thinking of ways to chisel." "25 Every lumberman seemed to be able to suggest ways of beating the code.

23Vause, "Administration of the NIRA," p. 112.

${ }^{24}$ Vause, "Administration of the NIRA," supplement, n.p.

${ }^{25}$ Vause, "Administration of the NIRA," p. 94. 
Conmenting upon the lumber code, Colonel William B. Greeley privately admitted that "'. . there are a lot of lumbermen who would like to see the whole thing kicked into a cocked hat." 26 And much to the dellght of most lumbermen, the NRA did suspend code price provisions-the most annoying aspect of the lumber code-mon December 22, 1934.

Chiseling on Section $7(a)$ of the NIRA was a relatively easy matter for the lumber industry. The fear of unemployment was a mighty tool used by lumber operators over their employees. Workers had to report violations of Section $7(a)$ in order for compliance to occur; but when employers told their workers that ". . . they had better keep their mouths shut or they would all get fired..." it is doubtful that many workers would complain. 27 Outside the Portland area, the NRA was not a great stimulus to unionism in Oregon's lumber industry. After the NRA was declared unconstitutional in May of 1935, many Portland-area businessmen at first stated that they would continue the spirit of the NRA locally by maintaining their present wage and hour scales. A survey, conducted by the Oregonian on June 1, 1935, among fourteen different types of business in Portland, found "a practically unanimous" agreement among executives that: "'We have made no changes in wages or hours. "128 The Oregon Labor Press cormented that ". . we

26. Vause, "Administration of the NIRA," p. 119.

27 Vause, "Administration of the NIRA," p. 131.

$28_{\text {Sunday Oregonian, June 2, } 1935, \text { p. } 1 .}$ 
have found the consensus of opinion to be in favor of voluntarily continuing NRA fair trade practices, code wages and maximum hours."29

But their attitudes and actions gradually began to change. By September of 1935, the spirit of the IRA was, for all practical purposes, nonexistent in Oregon. A trend towards increasing hours, lowering wages, and cutting prices had begun in June of 1935 and from July through August 15, it was, reported that 133 Oregon firms had ignored what previously had been their guidelines on operation--NRA codes. 30 Although this was a very small sample of the entire business community of Oregon, it is Iikely that this report was indicative of a mass movement among businessmen away from NRA concepts and towards free-market competitive ideals.

Obviously, it is impossible to offer a blanket assessment of the response of Oregon's business community to the NRA. The lumber industry, the state's largest industry, was generally antagonistic to the NRA. The attitudes of retail firms, however, varied, depending upon size, location and clientele. Thus, it cannot be said that the business community responded in any kind of united action or like fashion towards the NRA.

Organized Labor and the NRA: A Case of Pragmatic Enthusiasm

The pragmatic enthusiasm of organized labor for section $7(a)$ of the NIRA, was voiced emphatically by the weekly Oregon Labor Press, "The Official Publication of the Central Labor Council of Portland 30 Oregonian, Sept. 2,1935 , p. 1. 
and Vicinity and the Oregon State Federation of Labor." The OLP told Its readers that "The government of the United States has estabIlshed your legal right to organize!" 31 But it also warned its readers that:

Labor will either organize, OR IT WIIC BE HERDED. . . . It is not up to General Johnson to tell labor or employers whether he is organizing: them or not. IT IS UP TO LABOR TO ORGANIZE. - . The government is helping industry to organize. Labor has to do its job itself, as it should. .. . THE THING IO DO TODAY IS TO FORM UNIONS EVERYWHERE. EVERY AMERICAN WORKER OUGHT TO BE IN A UNION. 32

The OLP voiced this rather guarded support for the NRA a number of times. 33

Oregon's AFL officials were keenly aware of the fact that workers would gain only those benefits for which they fought. Shortly after the act became law, the OLP worried because labor was not included in the formation of NRA codes. ${ }^{34}$ Ben T. Osborne, Executive SecretaryTreasurer of the Oregon State AFL, took a realistic view of the NIRA when he commented in his Annual Report that "The recovery act will either prove to be the greatest blessing or the greatest curse which has come to organized labor in all its history in this nation." 35

$31_{\text {OLP, }}$ June 30,1933, p. 1.

32 Editorial, OLP, July 28, 1933, p. 2.

33 OLP, June 16, p. 1, Sept. 22, p. 3, 1933; Editorial, June 16, p. 2, June 30 , p. 2, Juiy 21 , p. 2, Aug. 11, p. 3, Aug. 25, p. 3. Sept. 1, p. 4, 1933, March 9, p. 2, 1934.

34 Editorial, OLP, July 14,1933, p. 2.

35 oLP, Aug. 11, 1933, p. 4. 
While Section $7(a)$ was a valuable piece of legislation for the furtherance of the goals of organized labor, it was only worth as much as was demanded under its guidelines.

Both the efforts of labor organizers and the realization by the unorganized worker that unionism was indeed feasible under Section $7(a)$ led to a great upsurge in labor activity and labor organization in Oregon, particularly in the Portland area. Especially active were longshoremen, butchers, municipal employees, barbers, retail clerks, laundry workers, furniture workers, textile workers, loggers, and sawmill workers. By late August of 1933, 3,000 new members were added to Portland AFL locals, of which about one-third were longshoremen and another third were sawmill and timber workers. In the latter half of 1933, twenty-five new unions were organized in the Portland area alone. The following year an additional twenty new unions were added to the Portland AFL rollcall. 36 Gust Anderson, Secretary of the Central Labor Council of Portland, commented glowingly in the early fall of 1935 that "Since the enactment of the National Recovery Act to the present time, the membership in Portland has almost doubled and organized labor is growing by leaps and bounds." 37 Labor did fight for its rights under Section $7(a)$, and to a large degree it did gain the benefits it sought. But its rights were not always easily won, for there was definitely less than a compatible relationship in existence between labor and Oregon's elected officials during the 1930's.

$$
\begin{aligned}
& \text { 36 OLP, Aug. } 25,1933, \text { p. 1, Jan. 4, 1935, p. } 1 . \\
& \text { 37 } \\
& \text { OLP; Sept. 6, 1935, sec. 2, p. 4. }
\end{aligned}
$$


The Oregon Labor Press referred to Governor Julius I. Meier, of the Portland retail firm of Meier \& Frank, as ". . Oregon's prize dumbbell governor . . "38 Union officials knew that Meier held a mutually unfriendly opinion of labor. He alienated workers badly by calling out the State Militia in July 1934 to assist strike breakers in crossing picket lines during the bitter Portland longshore strike. Lasting through the spring and summer the affair was probably the most dramatic strike that Portland, or Oregon, has ever witnessed. Meier was not alone in his actions against striking longshoremen. Portland's mayor, Joseph Carson-who was typically termed by labor as ". . an overgrown kid that. is trying to fill a he-man job. . "39-called out 500 regular and special policemen in late June to patrol the waterfront. In addition, Martin T. Pratt, Multnomah County Sheriff, had a contingent of his deputies on the docks. The Oregon AFL responded by passing a resolution which condemned their use of force--strikers were eventually flred upon with four injuries occurring--during the Iongshore strike. 40

The relationship between Governor Charles H. Martin, who took office in January of 1935, and organized labor was, to say the least, strained. Martin, a Democrat and a retired Army Major-General who was referred to as "Tin Pants Martin" by many Oregonians, delighted in antagonizing labor. Martin's solution, which he suggested to the

$$
\begin{aligned}
& 38_{\text {OLP, Jan. } 1,1934, \text { p. } 2 .} \\
& { }^{39} \text { OLP, Oct. } 4.1935, \text { p. } 1 . \\
& 40_{\text {OLP }} \text {, Aug. } 31,1934, \text { p. I. }
\end{aligned}
$$


sheriffs of the state, for dealing with labor organizers-whom he called "pestiferous peewees"4I--and strikers was to". . beat hell out of 'em! . ." and to "Crack their damn heads! Those fellows are there for nothing but trouble--give it to them!" If strike situations ever looked as if they might get out of hand, he noted that "We have thirtyfive hundred national guardsmen in the State, and each of them knows how to use a rifle!"42 Martin was more than willing to heed his own advice during labor disturbances-a fact which drew no mean amount of wrath from the union spokesmen who claimed that he was merely ". . munning true to form..." when he called our armed forces to combat strikers. 43

Organized labor had almost as mach bureaucratic difficulty with the state offices of the NRA as it had problems with Oregon's officials. Before the NRA had been in existence for even six months, it was noted that "Complaints to NRA get exactly nowhere at present. They may be changed. But that's how it is today. You can complain and get in return a nice form letter." 44 When labor's complaints were decided upon by the state office, decisions typically went in favor of management. The main complaint registered by labor was that Edgar Freed had no

4IIetter, Charles H. Martin to Walter E. Pearson, May 16, 1935 , Oregon Historical Society Manuscript Collection, Charles H. Martin Papers.

42Quoted in Richard I. Nueberger, Our Promised Land (New York: The Macmillan Company, 1938), p. 315.

430IP, June 14, 1935, p. 1 .

${ }^{44}$ OLP, Oct. 20,1933, p. 1. 
sympathy for the position of labor. Labor officials even had trouble In just seeing Freed. ${ }^{45}$ The Portland labor organizations were evidently the only ones who received much attention in the state director's office.

The Salem Trades and Labor Council once complained that:

The IRA stafe in Portland . . has no time for Salem. Complaints receive no attention when they come from Salem. Portland, the so-called metropolis, has hogged the services of the NRA staff just as it hogs everything else . . . all Salem gets is a nice large goose egg. This is not a recent development, but has been a permanent condition. ${ }^{4}$

There is little doubt that the labor policies of the state office of the IRA, when combined with the vacillating labor policy of Hugh Johnson, led to a considerable amount of disappointment and frustration on the part of organized labor in Oregon.

The Oregon Labor Press devoted little space--edftorial or otherwise--to the demise of the NRA. Almost all attention, in the spring and summer of 1935, was turned to the National Labor Relations Act, or Wagner Act, which was an offspring of Section 7 of the NIRA. But organized labor was, nevertheless, not happy with the Supreme Court decision which struck down the IRA. As the Oregon Labor Press explained, the judges' ruling caused working men and women to feel "that they are without the protection of the Federal Constitution in the field of industrial relations." 47 Also regrettable to organized labor was the ". . Inevitable resumption of child labor exploitation

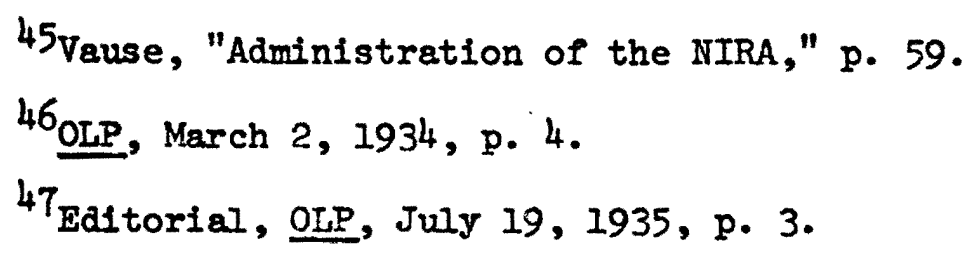


by antisocial employers." 48 However, even though the NRA and Section 7 (a) were gone, the NRA had given labor a much needed boost. OrganizatIon within labor had increased and workers were fairly confident that at least they had a foothold in the field of labor relations. 49

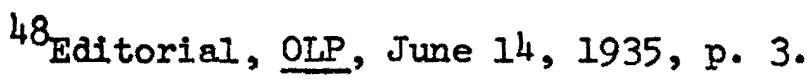
$49_{\text {Editorial, OLP, June } 21,1935, \text { p. } 3 .}$ 


\section{CHAPTER III}

\section{OREGON, THE HATION AND THE BLUE EAGLE: \\ COMPARISONS AND CONTRASTS}

The response of Oregon to the NRA roughly paralleled the response nation-wide. Neither the public, the business community, nor labor in Oregon differed seriously from their counterparts in other states. Furthermore, the operations, and even the problems, of the NRA's office in Oregon were similar to those of the NRA headquarters in Washington.

Interesting comparisons and contrasts can be drawn between Edgar Freed, head of the NRA in Oregon, and Hugh Johnson, national director of the IRA. Both had been officers in the Army and both viewed the Blue Eagle drive as something of a military operation. Johnson had an enthusiasm for his fob that is characterized by one historian as ". . the frontier abendon of a boy raised in the Cherokee Strip."I Freed, however, spent most of his time in his law firm, away from the state NRA offices. ${ }^{2}$ Both Johnson and Freed drew the wrath of Iabor upon themselves, but in different ways. Johnson antagonized labor by paying too much attention to it; he continually and unnecessarily

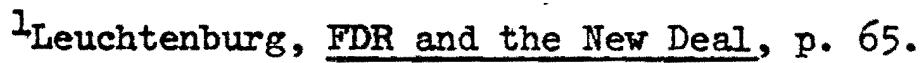

2Vause, "Administration of the NIRA," p. 58. Most of the information in this section on Freed is taken from Vause, pp. 58-63. Vause worked around the state NRA offices for a period of months researching his thesis. 
Intervenes in labor disputes, sometimes without the authority to do so in the first place. Freed angered labor by virtually ignoring it; he felt that the complaints of workers were not "'business-like." 3 Johnson was available to see almost anyone without an appointment. Freed was very exclusive in who he saw at his NRA office--he saw people by appointment only-and those people he did meet with were typically prominent businessmen and politicians. In late 1933 and early 1934 Francis Clare Vause, a Reed College senior, spent a great deal of time in the offices of the state NRA while working on his thesis. During. this time he was never granted an interview with Freed.

Johnson and Freed also had similar relationships with their chief assistants, Donald R. Richberg and Frank Messenger. Just as Johnson and Richberg. were almost constantly at odds with one another, Freed and Messenger never got along very well. Messenger, who had been district compliance director before the Compliance Division of the NRA was reorganized along state lines in early 1934, was openly resentful of his demotion to executive assistant to Freed. An eyewitness to Messenger and Freed's relationship commented that "they dislike each other heartily and there is friction at every turn. A number of open flares have occurred." 4 Messenger was eventually transferred to Seattle as trade compliance officer. C. Laird McKenna, a Portland attorney, who had been legal advisor to Messenger and who later became legal advisor to Freed,

3Vause, "Administration of the NIRA," p. 60.

"Vause, "Administration of the NIRA," p. $6 I$. 
assumed the position of executive assistant in the spring of 1934 . During the final eight weeks of the NRA's Itfespan, McKenna became state director of the NRA.

Parallels to the response of many state governments to the NRA can be found in Oregon's thirty-seventh and thirty-eighth legislative assemblies. By the end of 1933, twelve states passed "Little NRA" statutes-acts designed to supplement the NRA in one way or another-at the encouragement of federal officials. Three more states passed little NRA's, or state recovery acts, by March of 1935. Little NRA bills also reached the floors of twenty other legislatures. 5 If additional little NRA bills had been introduced in the summer of 1933, when the NRA was at its height of popularity, state recovery acts might. have proliferated. But most state legislatures had adjourned by the time federal officials began their drive for little NRA's. When most state legislatures reconvened in early 1935, enthusiasm for the NRA had dwindled.

The intent of the various state recovery acts ranged from providIng state enforcement of IRA codes, to establishing state codes of fair competition, to suspending state anti-trust laws. Bills formulated by federal officials that embodied all three of these aspects, which were

5 See Iewis Mayers, ed., A Handbook of NRA (2nd. èd. New York and Washington: Federal Codes, Inc., 1934), pp. 397-436, for a compilation of state NRA codes which were in effect by the first of 1934. Patterson, The New Deal and the States, pp. 112-18 gives a general survey and assessment of the states' political responses to the NRA. States having little NRA statutes by 1934 were California, Colorado, Kansas, Massachusetts, New Jersey, New York, Ohio, Texas, Utah, Virginia, Wisconsin, and Wyoming. Indiana, New Mexico and Washington passed state recovery acts by March of 1935. 
called "model little NRA's," were not in a clear majority in actual state recovery acts that became law.

Ne1ther geographical, industrial, nor agricultural factors influenced the passage of little NRA's by states, although the most common opposition came from rural bloss. Much like the nation's response to the NRA in general, the chance of a state recovery bill becoming a statute depended more upon the time it was introduced than anything else.

Very little is known about how effective little NRA's actually were in those states which had them. James T. Patterson, the foremost authority upon the New Deal and the states, can offer little more than a general overview of the political responses of the states to the NRA. However, considering the difficulty with which the NRA operated at the national level, it is doubtful that the states did much better.

Iittle NRA bills were introduced in the Oregon House during both the special session of the thirty-seventh assembly, which met in late 1933, and the regular session of the thirty-eighth assembly in early 1935. Multnomah County Democratic Representative William L: Dickson's House Bill 55, "To encourage state and national industrial recovery by cooperating with national government in fostering fair competition; and declaring an emergency," passed the special session of the House In amended form by a vote of forty-two to seventeen. 6 The bill was

- 6see Oregon, Journals of the Senate and House, 37th Legislative Assembly, $2 d$ special session (Salem: State Printing Office, 1933) and Oregon, Journals of the Senate and House, 38th Legislative Assembly (Salem: State Printing Office, 1935). 
tabled in the predominantly Republican Senate, never to be mentioned again. In 1935, Dickson, three other Democratic representatives, two Republican representatives and two senators, one a Democrat and the other a Republican, introduced another House Bill (HB 103) which read: "To provide a state industrial recovery act; and declaring an emergency." This bill--a model act prepared by the MRA--passed the House and was on the table of the Senate unt1l three days before final adjournment. The Senate passed the bill and it was signed by the President and the Speaker one day before adjoumment. However, the act's fate was to be pocket vetoed by Governor Martin.

One Irony of. House Bill 103 is that Governor Martin had earlier sent a message to the House before it was passed in which he stated that:

I am hopeful that this State Recovery Act, which I am convinced is essentially fair to the public to the employe and to the employer, will be enacted by the Oregon state legislature.?

But the supreme irony of the bill is that Martin submitted the proposed act to the House in the first placel Martin's initial support and later pocket veto of the act can only be explained as an exercise in political maneuvering, since the bill was not amended in either the House or the Senate. Martin had pledged in his campaign to ". . place Oregon definitely in line..." With the New Deal. 8 However, Martin

TOregon, Journals, 38th Assembly, p. 348. 80regon, Journals, 38th Assembly, p. 347 . 
had a peculiarly short memory when it actually came to supporting the New Deal. 9

Martin, whose election campaign was based upon a law and order and a pro-liew Deel platform, subsequently changed his tune. He contended that "'. . the New Deal's social security program is driving this country into national socialism." Declaring himself a "Hoover Democrat" regarding federal relief, Martin said that "3. . democratic nations have lost their moral force through pampering their people. "I0 One disenchanted liberal Oregon Democrat commented that "'Whenever I recall that I voted for him, I am so humiliated that I feel like migrating to South America to live among the Indians of the upper Amazon for the balance of my natural life." 11

Martin's actions regarding public power underscored his opposition to Roosevelt's program. The governor favored private, rather than public, control of the electric power which could result from harnessing the Columbia River. He militantly opposed the proposal for a Columbia Valley Authority, styled after the Tennessee Valley Authority. One member of the Oregon Public Utility Commission wrote

9 Robert E. Burton, Democrats of Oregon: The Pattern of Minority Polftics, 1900-1956 (Eugene: University of Oregon Books, 1970), p. 70; Earl Pomeroy, The Pacific Slope (New York: Alfred A. Knopf, Inc., 1965), pp. $243,249-50$.

${ }^{10}$ Salem Capital Journal, Oct. 14,1938, p. I; quoted in Burton, Democrats of Oregon, p. $82, \mathrm{n} .86$.

II Letter, Wilbur R. Brock to Walter M. Pierce, June 3, 1973, University of Oregon Library, Walter M. Pierce Papers; quoted in Burton, Democrats of Oregon, p. 82. 
that "Politics are certainly funny. Here I am supporting Roosevelt's power program and am opposed by a man [Martin] who was elected on a program to support the President and then [I was] ordered. . . to fight the President on Bonneville. "12 The only time Martin seemed to be a Iriend of Roosevelt and the New Deal was when he was campaigning for office and when Roosevelt visited the state.

Gerald D. Nash comments, in a history of western America during the twentieth century, that "Although initial enthusiasm for the National Recovery Administration.. was high, in most western states it waned toward the end of 1933."13 Oregon was no exception.

Western enthusiasm for the New Deal itself followed the general trend of sentiment toward the NRA. James T. Patterson comments that, "W1th the possibie exception of the South, no section seems to have resisted so obdurately the plans of the federal government [as did the West during the 1930's]."14 Bouyant approval of the New Deal rapidly turned to grudging acceptance and then to suspicion in much of the West by the mid-thirties. The rejection of the New Deal by the West

12 Ietter, Charles M. Thomas to Walter F. Pierce, June 11, 1935, University of Oregon Library, Walter M. Pierce Papers; quoted in Burton, Democrats of Oregon, p. 83.

13 Gerald D. Nash, The American West in the Twentieth Century: A Short History of an Urban Oasis (Englewood Cliffs, New Jersey: PrenticeHa]1, Inc., 1973), p. 161 .

14 James T. Patterson, "The New Deal in the West," Pacific Historical Review, XXXVIII (Aug., 1969), 320. The following discussion of the response of western states to the New Deal is drawn from Patterson's article. 
rested upon, among other things, resistance to federal labor reforms and federal relief. But there was also a lack of progressive state administrations in the West during the Depression. Western states considered Washington to be encroaching upon their rights when it introduced programs in which it controlled the main part of financing. They vere already inclined to distrust. federal bureaucrats. Federal actions which suggested that the Roosevelt administration favored the urban East--the Wagner act, the minimum wage law, and heavy relief spending In eastern cities--aggrsvated Western disenchantment with the New Deal. The NRA did seem to help the national economy in the early sumer of 1933, when factory production went up from an index of 56 in March to 101 and industrial stocks rose from 63 to 109 . However, the market broke in mid-JuIy. The boom was basically the result of businessmen attempting to produce, sell and buy as much as possible before IRA codes took effect. Whether Oregon's economy followed the national pattern of boom-and-bust is a matter of conjecture, since there is a lack of sophisticated economic statistics for the state in this period--especially upon a month-by-month basis. But a logical assumption to make would be that Oregon's economy did not follow the national pattern in the early summer of 1933 because the state's econony was not based upon factory production, but extractive industries. Oregonians lost most--if not all--of their enthusiasm for the NRA shortly after they discovered that recovery could not be gained by signing a pledge, displaying an emblem In thetr window, and marching in a parade. 
Hugh Johnson concluded in mid-July of 1933 that the NRA should become a mass movement in order to garner popular support for the Blue Eagle. It was a gamble, but Johnson said that "'. . . It is a good gamble. I think I can put this thing over."115 Johnson's gamble paid off In Oregon during the Blue Eagle drive; but after the campaign, it produced few dividends. An observer of the NRA in Oregon during 1934 commented that:

It is claimed that the Blue Eagle drive was necessary as an emotional background for the whole recovery program. The trouble is that there now seems to be a considerable let-down from the former emotional heights-apublic reaction which threatens the success of much that has been established 16

A notable example of the decline in public enthusiasm for the NRA in Oregon occurred in November of 1934. Mayor Carson proclaimed the week of November 19 as Portland's first annual NRA compliance, week. ${ }^{17}$ While it would seem that civic activities would be abundant--if one were to Judge from the previous year's activity in Portland--no mass meetings, no pledge campaigns, and no parades occurred. IRA compliance week quietly began and ended in Portland with little attention being given it by the public. Other cities and states did not have any mass meetings or parades in the latter half of 1934 either. The NRA no

${ }^{15}$ Special Industrial Recovery Board, Proceedings, July 18, 19, 1933; quoted in Schlesinger, Coming of the New Deal, p. 113.

16 Vause, "Administration of the NIRA," p. 23.

17 Oregonian, November 11, p. 9, November 18, p. 19, 1934. 
longer solicited an enthusiastic response from the public.

The public's grasp of the NRA in 1934 and 1935 was no more concrete than it had been prior to the Blue Eagle drive in 1933. The NRA, slipping back to a position of a vaguely-conceived bureaucracy, was thought of as a false promise of recovery.

Much was expected of the IRA by the American people. In mid1933, the NRA was probably the most popular piece of legislation that the Thirty-third Congress has passed. The NRA provided a psychological stimulant for a short season; but when recovery was not forthcoming, public enthusiasm waned. Like so many applauded panaceas which turn out to be false, the NRA provided a convenient scapegoat upon which people could blame their economic maladies.

By 1934, the NRA was a disappointment to many people. Its failure was due to a number of factors: administrative bungling; its attempt to do too much at once by tackling every feasible industry rather than Just a few key ones; the failure of the Public Works Administration to spend its money more rapialy under the leadership of "Honest Harold" Ickes, thus not "priming". America's economic pump; mistaken assumptions upon the part of the government about the unselfishness of businessmen; and the essentially false analogy that was drawn between the functions and tasks of the NRA and the earlier War Industries Board. 18

Businessmen in general complained that the NRA was meddiing in their effairs. Small businessmen in particular denounced the NRA as 18 Hawley, New DeaI and Monopoly, p. 135. 
the harbinger of federally-sponsored cartels and monopolies which would force them out of business because of the restraints imposed upon them by NRA codes.

WiIliam Randolph Hearst declared that the initials "NRA" stood for "No Recovery Allowed." I9 The Darrow Committee's initial report on the NRA stated that "A return to the anti-trust laws.. . we believe to be one of the great needs of the times." 20 But most Oregon businessmen, far removed from the financial centers of America, had fek specific complaints about the NRA.

Small businessmen in Portland left no public record of dissatisfaction with the NRA, with the exception of I. I. Starr. However, Starr's frustration with the NRA came more from personal antagonism with Edgar Freed. James H. Cassell, executive-secretary of the Oregon Automobile Dealers' Association and a member of Oregon's Council of Code Authorities, contended in mid-March of 1935 that ". . the vast majority of small business men [sic] in Oregon--automotive, grocers, butchers, bakers, barbers and what not desire the reenactment. [sic] of the Nationa] Recovery Act."2l But considering how closely Oregon's response to the IRA follows the rest of the nation in other aspects, it would be $a$ somewhat tenuous position to place much stock in Cassell's comment.

19Schlesinger; Coming of the New Deal, p. 121.

20 Schlesinger, Coming of the New Deal, p. 133.

2ILetter, James H. CasselI to Frederick Steiwer, Dec. 14, 1934. Oregon Historical Society Manuscript Collection, Steiwer Papers. 
Oregon's lumber industry was part of the movement which Initiated the eventual suspension of lumber price provisions by the RRA in December of 1934. The West Coast Iumbermen's Association, in October of 1934 , had voted formally to discontinue minimum prices because they felt code prices were too high. Two months later the NRA abandoned price controls for the entire American lumber industry. 22

Organized labor in Oregon responded to the NRA in the same fashion as did the rest of organized labor in the nation. Labor's official newspaper, the Oregon Labor Press, was a mouthpiece for the national AFL. The Oregon Labor Press contained little in the way of distinctly local news in half of its four weekly pages; most of the news and articles it contained were dispatches from the American Federation of Labor News Service.

Just as a Kentucky State Federation of Labor handbill read "The United States Government Has Said IAABOR MUST ORGANIZE," the Oregon Labor Press said "Workers Forced to Organize." Just as the United Mine Workers Journal cautioned that "The [NIRA] will only be helpful to those who help themselves" and Sidney Hillman, President of the eastern-based Amalgamated Clothing Workers and member of the NRA's Labor Advisory Board, recognized that labor would only get out of the NRA what it put into it, the Oregon Labor Press said that labor would get out of the RRA "Only What We Fight For!"123 Pragmatic enthusiasm for the NRA was not Iimited

22 Hawley, New Deal and Monopoly, p. 115.

23Quoted in Schlesinger, Coming of the New Deal, p. 139; Bernstein, Turbulent Years, p. 75; Editorial, OLP, June 30, 1933, p. 2. 
to organized labor in Oregon; the entire American labor movement took a pragmatic view of the NRA.

Moreover, Oregon's labor movement was not alone in being both antagonized by and frustrated with state and local governments. Labor historian Irving Bernstein appropriately selected Turbulent Years as the title of his definitive history of the American labor movement in the 1930's. Bernstein's title is indicative of the environment in which the entire American Iabor movement fought for recognition during the Depression. The 1930's were indeed a decade of strife for all of American labor in its relations with both management and state and local governments.

Irving Bernstein comments that ". . Section $7(a)$. . was the spark that rekindled the spirit of unionism within American labor." 24 Numerous strikes--involving both labor militancy and governmental hostility--occurred from North to South and East to West in America. Oregon labor was certainly part of the movement toward unionism in America after the NIRA was passed.

Organized labor in Oregon shifted its attention from the NRA to the National Labor Relations Bill in early 1935, as did the rest of the American labor movement. American labor had little time or inclinstion to grieve over the death of the NRA in May of 1935; labor in the thirties was optimistic concerning its future.

24 Bernstein, Turbulent Years, p. 37. 
The value of a state study lies in either corroborating or refutIng the interpretations which are given a general topic for the nation as a whole. This paper buttresses the dominant historical interpretations of America's response to the NRA. Oregon reacted in an almost identical fashion to the NRA as did the rest of the United States. 


\section{A SETECTED BIBLIOGRAPHY}

BOOKS

Bernstein, Irving. Turbulent Years: A History of the American Worker, 1933-1941. Sentry Edition. Boston: Houghton Mifflin, 1969 .

Blum, John M.; Morgan, Edmund S.; Rose, Willie Lee; Schlesinger, Arthur M., Jr; Stampp, Kenneth M.; and Woodward, C. Vann. The National Experience: A History of the United States. 3rd ed. New York: Harcourt Brace Jovanovich, Inc., 1973.

Burton, Robert E. Democrats of Oregon: The Pattern of Minority Politics, 1900-1956. Eugene: University of Oregon, 1970.

CarrolI, Peter N., and Noble, David W. The Restless Centuries: A History of the American People. Minneapolis, Minnesota: Burgess Publishing Company, 1973.

Conkin, Paul E. The New Deal. New York: Thomas Y. Crowell Company, Inc., 1967.

Current, Richard N.; Williams, T. Harry; and Freidel, Frank. American History: A Survey. 3rd ed. Borzoi Books. New York: Alfred A. Knope, Inc., 1971.

Dearing, Charles L.; Holman, Paul T.; Lorwin, Lewis L.; and Lyon, Leverett $S$. The ABC of the NRA. Washington, D. C.: The Brookings Institution, 1934 .

Degler, Carl N.; Cochran, Thomas C.; De Santis, Vincent P.; Hamilton, Holman; Harbaugh, William H.; Link, Arthur S.; Nye, Russel B.; Potter, David $\mathrm{M}_{+}$; and Ver Stegg, Clarence $L$. The Democratic Experience: A Short American History. 3rd ed. Vol. II. Glenview, Illinois: Scott, Foresman and Company, 1973.

Garraty, John A. A Short History of the American Nation. New York: Harper \& Row, 1974.

Graham, Otis I, Jr., ed. The New Deal: The Critical Issues. Boston: Little, Brown and Company, Inc., 1971.

Hawley, Ellis W. The New Deal and the Problem of MonopoIy: A Study in Economic Ambivalence. Princeton, New Jersey: Princeton University Press, 1966. 
Holstadter, Richard; Miller, William; and Aaron, Daniel. The United States: The History of a Republic. 2nd ed. Englewood Cliffs, New Jersey: Prentice-Hall, Inc., 1967.

Johansen, Dorothy 0. Fmpire of the Columbia: A History of the Pacific Northwest. 2nd ed. New York: Harper \& Row, 1967.

Johnson, Hugh S. The Blue Eagle from Egg to Earth. Garden City, New York: Doubleday, Doran \& Company, Inc., 1935.

Leuchtenburg, William F. Franklin D. Roosevelt and the New Deal, 19321940. Harper Torchbooks. New York: Harper \& Row, Inc., 1963.

Lyon, Leverett S.; Homan, Paul T.; Terborgh, George; Lorwin, Lewis L.; Dearing, Charles L.; and Marshall, Leon C. The National Recovery Administration: An Analysis and Appraisal. Washington, D.C.: The Brookings Institution, 1935.

McDonald, Forrest; Decker, Leslie E.; and Govan, Thomas P. The Last Best Hope: A History of the United States. Part 3. Reading, Massachusetts: Addison-Wesley Publishing Company, 1972.

Mayers, Lewis, ed. A Handbook of NRA. 2nd ed. New York and Washingion: Federal Codes, Inc., 1934.

Mitchell, Broadus. Depression Decade: From New Era through New Deal, 1929-1941. Harper Torchbooks. New York: Harper \& Row, Inc., 1947.

Morison, Samuel Eliot; Commager, Henry Steels; and Leuchtenburg, William E. The Growth of the American Republic. Vol. II. 6th ed. New York: Oxford University Press, 1969.

Nash, Gerald D. The American West in the Twentieth Century: A Short History of an Urban Oasis. Englewood Cliffs, New Jersey: Prentice-HaIl, Inc., 1973.

Nusberger, Richard L. Our Promised Land. New Yorik: The Macmillan Compeny, 1938.

Patterson, James T. The New Deal and the States: Federalism in Transition. Princeton, New Jersey: Princeton University Press, 1969.

Perkins, Frances. The Roosevelt I Knew. Harper Colophon Books. New York: Harper \& Row, Inc., 1946.

Pomeroy, Earl. The Pacific Slope: A History of California, Oregon, Washington, Idaho, Utah, and Nevada. Borzoi Books. New York: Alfred A. Knopf, Inc., 1965. 
Richberg, Donald R. My Hero: 'The Indiscreet Memoirs of an Eventful but Unheroic Life. New York: G. P. Putnam's Sons, 1954.

Richberg, Donald R. The Rainbow. Garden City, New York: Doubleday, Doran \& Company, Inc., 1936.

Roos, Charles Frederick. IRA Economic Planning. Bloomington, Indiana: The Principia Press, 1937. New York: Da Capo Press, Inc., Reprint, 1971.

Rosenman, Samuel I., ed. The Public Papers and Addresses of Franklin D. Roosevelt. 13 vols. New York: Random House, vols. 1-5; The Macmillan Company, vols. 6-9; Harper \& Bros., vols. 9-13, 19381950.

Rozwenc, Edwin C. The Making of American Society: An Institutional and Intellectual History of the United States. Vol. II. Boston: Allyn and Bacon, Inc., 1973.

Schlesinger, Arthur M., Jr. The Age of Roosevelt: The Coming of the New Deal, 1933-1935. Sentry Edition. Boston: Houghton Mifflin, 1958.

Vadney, Thomas E. The Wayward Liberal: A Political Biography of Donald Rlchberg. Lexington, Kentucky: The University Press of Kentucky, 1970.

ARTICLES

Leuchtenburg, William E. "The New Deal and the Analogue of War." "Change and Continuity in Twentieth-Century America. Edited by John Braeman, Robert H. Bremner, and Everett Walters. Harper Colophon Books. New York: Harper \& Row, Inc., 1966.

Nash, Gerald D. "Experiments in Industrial Mobilizations: WIB and NRA." Mid-America, XIV (July, 1963), 157-74.

Patterson, James T. "The New Deal in the West." Pacific Historical Review, XXXVIII (Aug., 1969), 317-27.

Radosh, Ronald. "The Myth of the New Deal." A New History of Leviathan: Essays on the Rise of the American Corporate State. Edited by Ronald Radosh and Murry N. Rothbard. New York: E. P. Dutton \& Company, Inc., 1972. 
Rothbard, Murry N. "War Collectivism in Worla War I." A New History of Leviathan: Essays on the Rise of the American Corporate State. Edited by Ronald Radosh and Murry N. Rothbard. New Yori: E. P. Dutton \& Company, Inc., 1972.

Wilson, William H. "How the Chamber of Commerce Viewed the NRA: A Re-examination." Mid-America, XIIV (April, 1962), 95-108.

PERIODICALS

The Oregon Democrat. I (JuIy 6, 1933)--III (June 2I, 1935).

The Oregon Voter. IXXIV (July 29, 1933)--LXXIX (Dec. 29, 1934).

NEWSPAPERS

Oregonian: June 5, 1933-Feb. 25, 1939.

Oregon Journal. July 20; 1933-Sept. 20, 1936.

Oregon Labor Press. June 2, 1933-Nov. 15, 1935.

PUBLIC DOCUMENTS

National Recovery Administration, Speakers' Division. Pointed Paragraphs for Speakers: The Blue Eagle Drive. Washington, D. C.: 1933. Voices of the American Past: Readings in American History. Edited by Morton Borden. Lexington, Massachusetts : D. C. Heath and Company, 1972.

Oregon. Journals of the Senate and House. 37th Legislative Assembly, 2d. Special Session. Salem: State Printing Offices, 1933.

Oregon. Journals of the Senate and House. 38 th Legislative Assembly. Salem: State Printing Offices, 1935.

U. S. Congress. Senate. Emplovees of the National Recovery Administration. S. Doc. 164, 73rd Cong., 2nd sess., 1934.

U. S. Department of Commerce. Bureau of the Census. Fifteenth Census of the United States, 1930: Population, Vol. III. 
UWPUBLISHED MATERIALS

Vause, Francis Clare. "The Administration of the National Industrial Recovery Act with Particular Reference to the Iumber Industry." Unpublished Senior Thesis, Reed College, 1934.

MAIUSCRIPT COLIECTIONS

Martin (Charles H.) Papers. Oregon Historical Society Manuscript Collection. Portland, Oregon.

Stelwer (Frederick) Papers., Oregon Historical Society Manuscript Collection. Portland, Oregon. 